\title{
Pioneer annual vegetation of gravel-bed rivers: first insights on environmental drivers from three Apennine streams
}

\author{
Rossano Bolpagni, Alice Dalla Vecchia \\ Department of Chemistry, Life Sciences and Environmental Sustainability, University of Parma, Viale delle Scienze 11/A, I-43124 \\ Parma, Italy
}

\begin{abstract}
A huge knowledge gap exists on riverine pioneer vegetation. Despite its relevance in regulating the $\mathrm{C}$ metabolism at the catchment scale, and the triggering role in shrubs and trees establishment along riverbanks, little data is available on its environmental determinants. Indeed, most existing knowledge in this field refers to woody species or aquatic macrophytes neglecting the ecosystem relevance of ephemeral herbaceous vegetation. Focusing on three gravel bed rivers located in northern Italy (Baganza, Nure and Parma streams), the present study is aimed to evaluate the riverine ephemeral plant richness, considering both native and alien taxa, and the role of hydrogeomorphological disturbance and sediment quality in the observed richness patterns. At higher disturbance rates (e.g., larger river sizes), our data indicates a progressive decrease in overall plant richness, but also an increase in the coverage-abundance rates mainly due to alien species. This evidence confirms that variations in hydrology imply changes in pioneer plant species richness at in-stream periodically exposed sediments. More attention must be given to the vulnerability of pioneer vegetation to climate change and direct human impacts to fully understand the functioning of lotic ecosystems, especially the non-perennial ones.
\end{abstract}

\section{INTRODUCTION}

In recent years, the quantification of the interactions between hydromorphological processes and vegetation has supported the development of multiple conceptual models able to predict the responses of riverine plants to water force (Corenblit et al., 2007; Gurnell et al., 2016). A major output of these research advances is the identification of "critical zones" for physical ecosystem engineering of fluvial systems mediated by plants (Gurnell et al., 2016), where patchy vegetation assemblages interact directly with the fluvial disturbance and can partially drive the riverine evolution processes (Leyer, 2006; Corenblit et al., 2007).

About this, most of the available knowledge refers to woody species or aquatic macrophytes - identified as key “ecosystem engineers" (Thomaz and Cunha, 2010) - ne-

Corresponding author: rossano.bolpagni@unipr.it

Key words: herbaceous riverine plants; hydrogeomorphic disturbance; sediment granulometry; diversity; invasive species; EmiliaRomagna; North Italy.

Received: 9 May 2021.

Accepted: 6 October 2021.

This work is licensed under a Creative Commons Attribution NonCommercial 4.0 License (CC BY-NC 4.0).

${ }^{\circ}$ Copyright: the Author(s), 2021

Licensee PAGEPress, Italy

J. Limnol., 2021; 80(3):2052

DOI: 10.4081/jlimnol.2021.2052 glecting the ecological importance of ephemeral herbaceous vegetation and its ecological determinants (Leyer, 2006; Corenblit et al., 2014). Indeed, only few contributions explored the biological features of pioneer plants, focusing on exposed muds and marginal lentic water bodies, or on the role of river-floodplain connectivity in driving their multi-spatial distribution patterns (Salisbury, 1970; Leyer, 2006; Bolpagni and Piotti, 2015, 2016). Even if this vegetation plays a minor role in modulating the river dynamics, from a morphodynamical point of view these plant communities represent the initial stages of the establishment of shrubs (e.g., Salix spp.) and trees (e.g., Populus nigra L., Salix alba L.). Therefore, pioneer vegetation is involved in key functions such as regulating the mobility of river edges and creating landforms (Gurnell et al., 2012, 2016). Moreover, a growing number of data demonstrates the crucial role of riverine ephemeral vegetation in modulating the $\mathrm{C}$ metabolism at the catchment scale (Bolpagni et al., 2017, 2019; Mallast et al., 2020), with relevant implication on stream/river functioning (Gómez-Gener et al., 2021).

Furthermore, pioneer vegetation is also expected to have a high sensitivity to climate change, especially in the temperate regions where substantial changes in river discharges and flood magnitude are probable in the next decades, as well as the recurrence of flow cessation events (Datry et al., 2014; Messager et al., 2021). Lastly, pioneer annual vegetation of river corridors - comprised in the Chenopodion rubri and Bidention tripartitae alliances has been recognized as habitat of high conservation value by European designation [e.g., Annex I habitat in the EC Habitats Directive (92/43/EEC)]. It attains higher values of plant diversity compared to contiguous shrubby and woody stands, although riverine herbaceous stands are 
characterized by a greater "biotic acceptance" of alien species as richness in native species increases (Corenblit et al., 2014).

In this context, it becomes critical to integrate available knowledge on the role of hydrogeomorphic disturbance in driving herbaceous plant species richness to relate alien and native species along gradients of river discharge (Burkart, 2001; Corenblit et al., 2014). We expected that the abiotic determinants (e.g., flow and sediment granulometry) significantly explain the diversity patterns of ephemeral vegetation. Starting from this hypothesis, the present paper aimed at quantifying plant richness responses to the hydrogeomorphological disturbance (expressed in terms of river discharge and topography) and sediment quality (expressed in terms of granulometry), considering the contribution of both native and alien taxa.

\section{METHODS}

\section{Study area}

The study was carried out along three gravel bed rivers (Baganza, Nure and Parma streams) located in the Po Plain (northern Italy) (Fig. 1). The Po Plain is characterized by a mild continental climate with annual rainfall of $\sim 1000-1200 \mathrm{~mm}$ year ${ }^{-1}$ concentrated during fall (OctoberNovember). These streams have a pluvial hydrological regime with a predominant natural regulation. Their mean annual discharges for the period 1991-2011 are 5.2, 8.6 and $13.3 \mathrm{~m}^{3} \mathrm{~s}^{-1}$ for Baganza (BA), Nure (NU) and Parma (PR) streams, respectively; the bankfull width (mean \pm standard deviation) ranges from $117 \pm 35 \mathrm{~m}(\mathrm{BA})$ to $191 \pm 40 \mathrm{~m}$ (PR) (Burgazzi et al., 2017, 2020).
In the highly dynamic piedmont zone of each river, a study site was chosen corresponding to a stretch of approximately $600 \mathrm{~m}$ length, enclosing an active stretch with similar characteristics (e.g., meso-habitats arrangement). In presence of a braided behavior, data was collected along the main reach to consider riparian margins with equivalent hydrogeomorphic characteristics and to collect comparable results among streams.

\section{Experimental design and vegetation characterization}

During late summer 2014, at each study site herbaceous vegetation was described in 15 randomly distributed plots of $4 \mathrm{~m}^{2}$, in agreement with Chytrý and Otypková (2003) and Corenblit et al. (2014). All the species (both native and alien) were recognized, and their ground-projected cover area was estimated by 5 -per-cent-cover classes (from 0 to $100 \%$ ) assigning $1 \%$ and $3 \%$ respectively to rare and sporadic species (with cover-abundance percentages lower than 5\%). Plant nomenclature follows Bartolucci et al. (2018) for native species, Galasso et al. (2018) for the alien plants, and the updates reported by the Portal to Flora of Italy (http://dryades.units.it/floritaly/). Here, for alien taxa we considered both neophytes - including all taxa introduced after 1492 AC by humans - and archeophytes (Galasso et al., 2018). A specification is necessary for Setaria italica (L.) P.Beauv. ssp. viridis (L.) Thell. and Xanthium italicum Moretti, two of the most spread species in the riparian herbaceous vegetation in the Po basin (Bolpagni and Piotti, 2015, 2016), that must be considered, despite their specific epithets, alien taxa (Banfi and Galasso, 2010). Bidens vulgata Greene and Bidens frondosa L. have been grouped due to the impossibility of differentiating them as immature individuals.
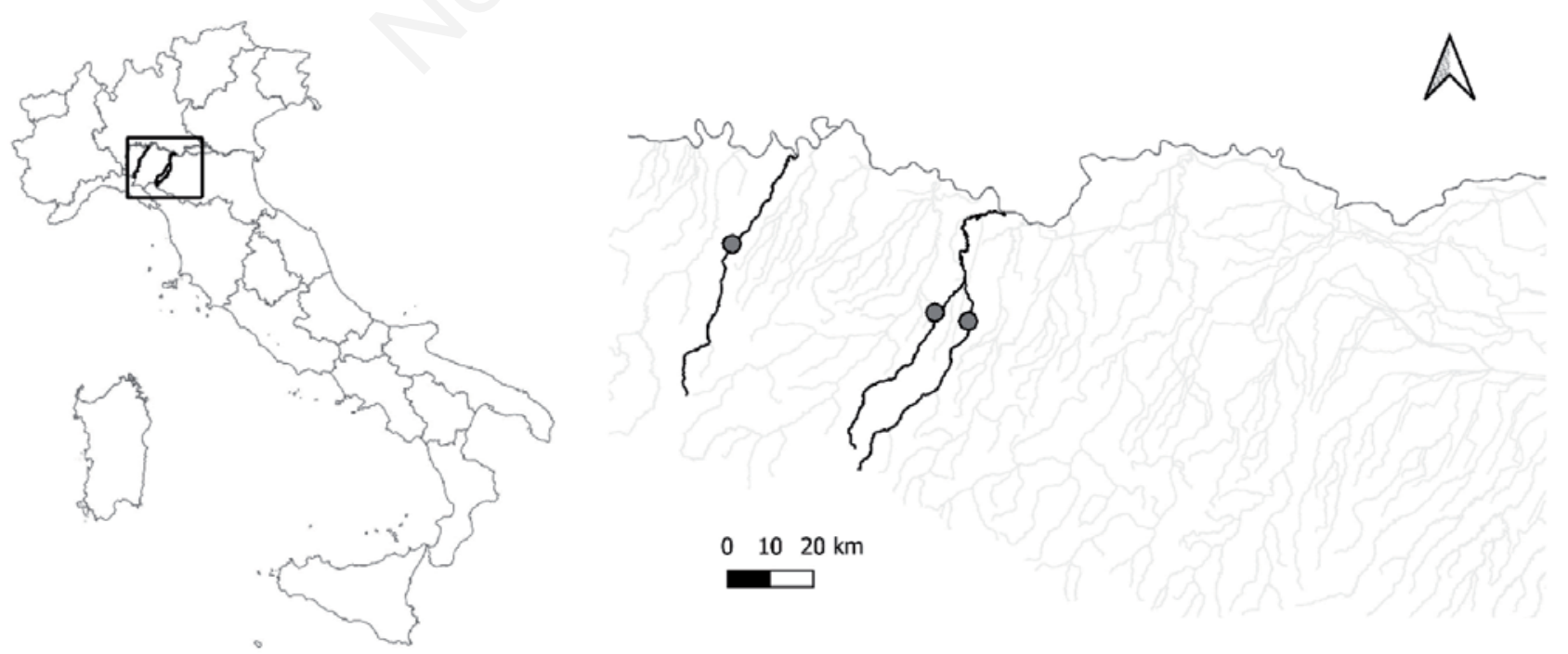

Fig. 1. Map of the study area with the location of sampled river stretches. 


\section{Environmental driver characterization}

Simultaneously with the vegetation characterization, the main hydrogeomorphic features of each study plot were estimated (Corenblit et al., 2014). The topography (HT = height above water base flow level) was characterized in relation to the summer base flow of the main channel during the study period by measuring the elevation and the distance (expressed in $\mathrm{m}$ ) from the active river channel edge. Surface sediment texture (ST) was defined in agreement with Wolman (1954).

\section{Data analysis}

A one-way ANOVA was performed on environmental determinants (HT and ST) data to account for the relative effect of site in R environment ( $R$ Core Team, 2021). Linear mixed models were used to test the effect of HT and ST on species richness and abundance, setting the site as random effect and HT and ST as fixed effect. We tested the models separately using the following response variables: total species richness (TR), native species richness (NR), alien species richness (AR), ratio between alien and native species richness (AR/NR) and ratio between alien and native species cover $(\mathrm{AC} / \mathrm{NC})$. Important outliers were removed from the dataset, and data was checked for assumptions before running the analyses. Data was not transformed although in some cases normality of residuals was not entirely met, because we found negligible differences in the outputs between the transformed and nontransformed models. All models were run in $\mathrm{R}$ environment, using the package "ImerTest" (Kuznetsova et al., 2017; R Core Team, 2021).

\section{RESULTS}

\section{Environment drivers}

The relative elevation of plots ranged between 10 and $146 \mathrm{~cm}$ above the summer base-flow level of studied streams. A significant increase in elevation as the mean river discharge increases was observed (one-way ANOVA, $\mathrm{F}=5.140, \mathrm{p}=0.010$ ). HT peaked at PR plots $(69 \pm 39 \mathrm{~cm})$, whilst the lowest average values were recorded at BA $(35 \pm 18 \mathrm{~cm})$ (Fig. 2). No statistical differences between rivers in sediment texture properties were observed (one-way ANOVA, $\mathrm{F}=0.7177, \mathrm{p}=0.494$ ) (Fig. 2). The average diameters of particle axes ranged between $2.2 \pm 0.6 \mathrm{~cm}(\mathrm{NU})$ and $2.4 \pm 0.6 \mathrm{~cm}(\mathrm{PR})$.

\section{Species richness and cover}

A total of 108 species was recorded, 68 taxa at PR sites (equal to $63 \%$ of the overall recognized species), and 66 taxa at BA and NU sites (61\%). The most widespread species, recorded at least in $50 \%$ of the sampled plots $(=22)$, were eight, with Xanthium italicum, Persicaria lapathifolia (L.) Delarbre ssp. lapathifolia, Echinochloa crus-galli (L.) P. Beauv., Setaria italica ssp. viridis, Populus x canadensis Moench, Ambrosia artemisiifolia L. and Bidens vulgata/frondosa found in $65 \%$ or more of sampled plots. X. italicum, an alien taxon, and P. lapathifolia ssp. lapathifolia were the only two species recorded in all the investigated plots (Tab. 1). The alien taxa accounted for 32.4\% (35 taxa) of the total diversity - and overall, they can be considered invasive, as for example A. artemisiifolia, Artemisia
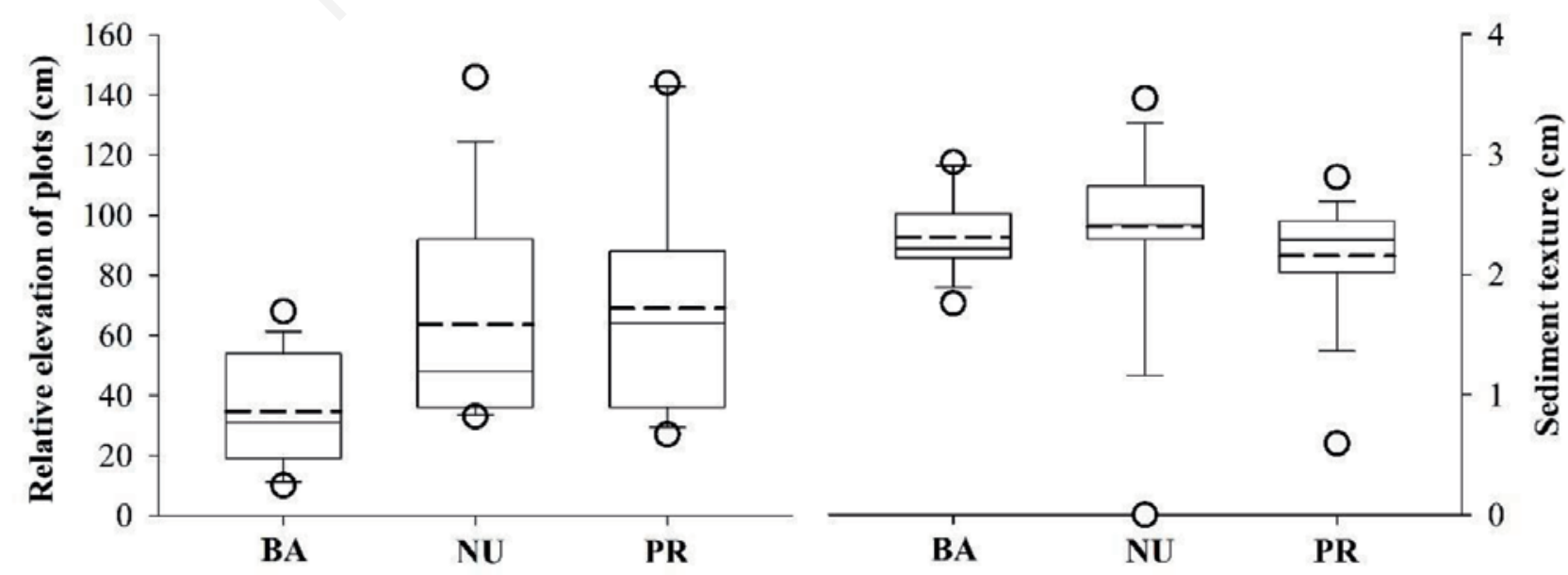

Fig. 2. Box-whiskers plots (minimum, $25 \%$, median, mean $=$ short-dashed line, $75 \%$, maximum, and outliers $=$ dots) showing variability $(\mathrm{n}=15)$ between rivers (BA, Baganza; NU, Nure; PR, Parma) in relative elevation of plots (left panel) and sediment texture (right panel). 
annua L., B. vulgata/frondosa and Euphorbia maculata L.

The average species number per plot was $21.2 \pm 6.1$. It peaked at BA plots, with an average value of $23.0 \pm 6.6$ species, while the lowest value was recorded at PR (20.3 \pm 5.6 ; Fig. 3). By separating the contribution of native and alien plant species, similar patterns were observed for the native ones, with a maximum of $12.8 \pm 3.7$ species per plot measured at BA site, and lower values for PR (12.2 \pm 4.1 species per plot) and NU (10.3 \pm 4.5$)$. The latter peaked at BA and NU with similar average values (10.2 and 10.1 species per plot, respectively), whereas the lowest values have been recognized at PR site (with an average alien species richness of 8.1) (Fig. 3).

The cover values overlapped the species richness data trends, with an overall average value of $48.8 \pm 28.0 \%$ per plot. The highest cover rates were recorded at BA site $(64.4 \pm 34.1 \%)$, whereas the lowest at NU site $(38.4 \pm 14.7$ $\%$; Fig. 3). Both the native and alien species yielded the maximum cover values at PR site, with a clear predominance of the alien ones, with rates in the range $38.7 \pm 18.0$ to $25.7 \pm 28.3 \%$, respectively (Fig. 3).

Concerning the mutual relationships between alien and native species richness and coverage (AR/NR and $\mathrm{AC} / \mathrm{NC}$, respectively), comparable trends were observed with the highest values recorded at NU plots for both descriptors (Fig. 4). The richness ratio (AR/NR) ranged between 0.4 and 2.0, whereas the cover ratio (AC/NC) showed values in the range of $0.22-8.80$, indicating a wider variability in the cover contribution of alien species across plots and sites compared to the species richness.

\section{Hydrogeomorphic and sediment drivers}

The linear mixed models evidenced a significant effect of HT on TR, NR and AC/NC. The relation is positive in all cases, i.e., we observed an increase in TR, NR and AC/NC with increasing HT (Table 2). AR was not influ-

Tab. 1. List of the most abundant species, considering all the species with a total cumulative detection $>30 \%$ ( 14 plots). For each taxon, the number of colonized plots and the mean cover values were reported, considering both the whole set of sampled rivers (Tot) and each river separately. Alien species are highlighted in bold.

\begin{tabular}{|c|c|c|c|c|c|c|c|c|}
\hline \multirow[b]{2}{*}{ Species } & \multicolumn{4}{|c|}{ Number of colonized plots } & \multicolumn{4}{|c|}{ Mean cover values } \\
\hline & Tot & BA & NU & PR & Tot & BA & NU & PR \\
\hline Xanthium italicum & 45 & 15 & 15 & 15 & 16.5 & 5.5 & 18.7 & 25.3 \\
\hline Persicaria lapathifolia ssp. lapathifolia & 45 & 15 & 15 & 15 & 6.0 & 3.8 & 1.3 & 12.7 \\
\hline Echinochloa crus-galli & 42 & 14 & 14 & 14 & 2.4 & 2.4 & 2.0 & 2.8 \\
\hline Setaria italica ssp. viridis & 40 & 12 & 14 & 14 & 2.2 & 1.0 & 2.3 & 3.5 \\
\hline Populus $x$ canadensis & 39 & 12 & 13 & 14 & 2.4 & 1.4 & 2.4 & 3.3 \\
\hline Ambrosia artemisiifolia & 36 & 15 & 15 & 6 & 10.5 & 19.3 & 2.8 & 9.5 \\
\hline Bidens vulgata/frondosa & 35 & 15 & 9 & 11 & 2.4 & 1.9 & 3.2 & 2.0 \\
\hline Panicum capillare & 28 & 14 & 13 & 1 & 2.6 & 1.8 & 3.5 & \\
\hline Digitaria sanguinalis & 22 & 6 & 9 & 7 & 1.7 & & 1.7 & \\
\hline Diplotaxis tenuifolia & 21 & 5 & 7 & 9 & 1.3 & 1.0 & 1.0 & 1.8 \\
\hline Persicaria lapathifolia ssp. pallida & 21 & 9 & 4 & 8 & 1.6 & 2.0 & 1.0 & 1.9 \\
\hline Amaranthus hybridus & 20 & 7 & $\mathbf{0}$ & 13 & 2.5 & & & 2.5 \\
\hline Chenopodium album & 20 & 7 & 3 & 10 & 1.1 & & 1.0 & 1.3 \\
\hline Polygonum arenastrum & 20 & 10 & 1 & 9 & 2.0 & 1.6 & & 2.4 \\
\hline Lysimachia arvensis & 19 & 9 & 7 & 3 & 2.0 & & 2.0 & \\
\hline Plantago lanceolata & 19 & 7 & 6 & 6 & 1.0 & & 1.0 & 1.0 \\
\hline Cuscuta campestris & 18 & 7 & 5 & 6 & 3.2 & 1.7 & 2.6 & 5.3 \\
\hline Trigonella alba & 18 & 0 & 7 & 11 & 3.0 & & 2.5 & 3.5 \\
\hline Barbarea vulgaris & 17 & 10 & 0 & 7 & 2.7 & 2.3 & & 3.0 \\
\hline Salix alba & 17 & 5 & 7 & 5 & 1.0 & & 1.0 & 1.0 \\
\hline Amaranthus blitum & 16 & 0 & 7 & 9 & 1.3 & & 1.0 & 1.6 \\
\hline Agrostis stolonifera & 15 & 9 & 1 & 5 & 2.3 & 3.5 & & 1.0 \\
\hline Daucus carota & 14 & 6 & 3 & 5 & 1.0 & 1.0 & 1.0 & 1.0 \\
\hline Euphorbia nutans & 14 & $\mathbf{0}$ & 14 & $\mathbf{0}$ & 2.9 & & 2.9 & \\
\hline Medicago lupulina & 14 & 10 & 2 & 2 & 1.3 & 2.0 & 1.0 & 1.0 \\
\hline
\end{tabular}


enced by any of our explanatory variables, nor was AR/NR, although a marginally significant relationship between AR and HT was found (Tab. 2). No relation was found between ST and any of the response variables investigated.

\section{DISCUSSION}

The variation in hydrology implies changes in pioneer plant species richness at in-stream periodically exposed sediments. These results are consistent with findings from

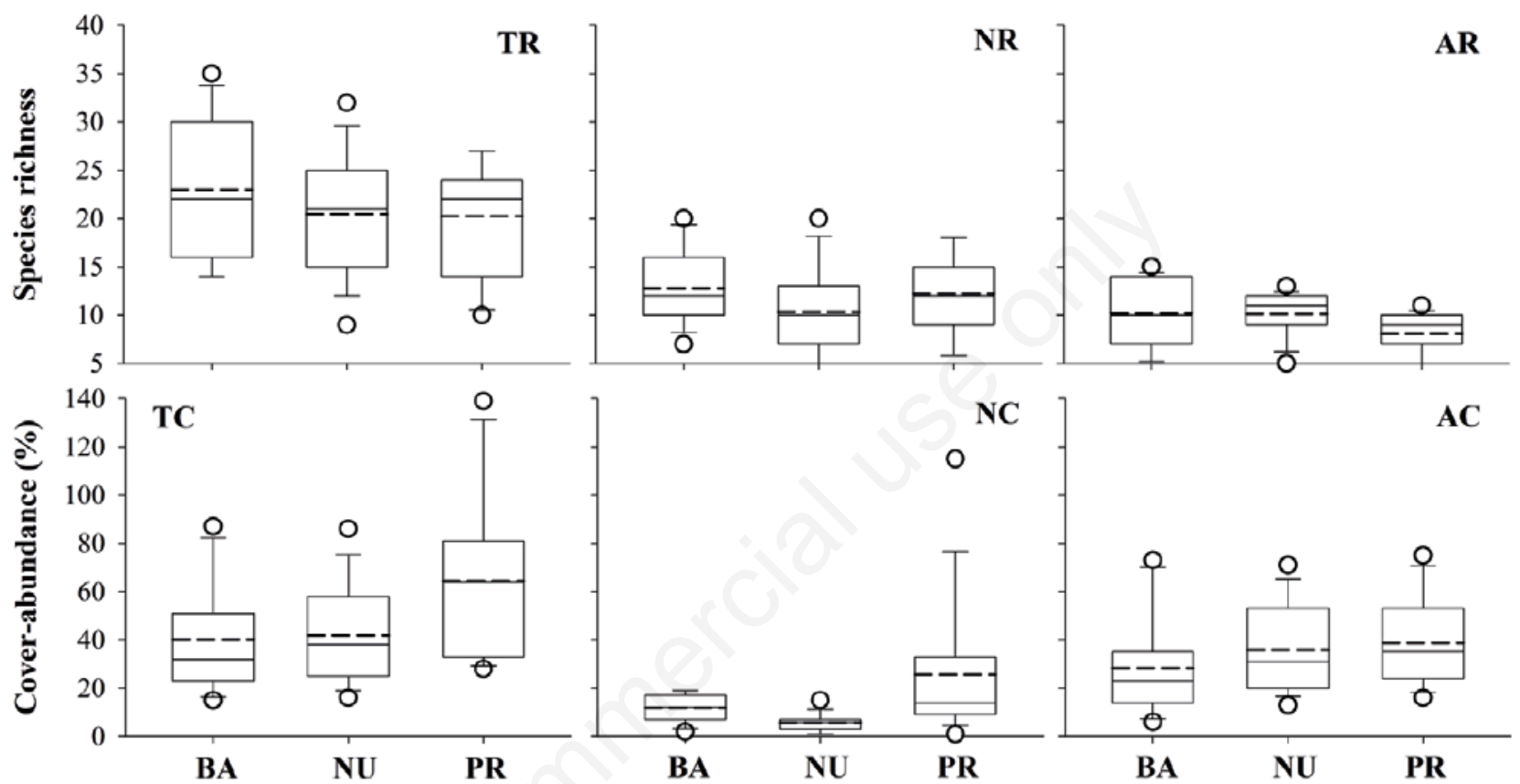

Fig. 3. Box-whiskers plots (minimum, $25 \%$, median, mean $=$ short-dashed line, $75 \%$, maximum, and outliers $=$ dots) showing variability $(\mathrm{n}=15)$ between rivers (BA, Baganza; NU, Nure; PR, Parma) in species richness (upper panels) and species cover (lower panels), both considering all the taxa combined (TR, total richness; TC, total cover), or the values for native (NR, native richness; NC, native cover) and alien (AR, alien richness; AC, alien cover) plants separately.

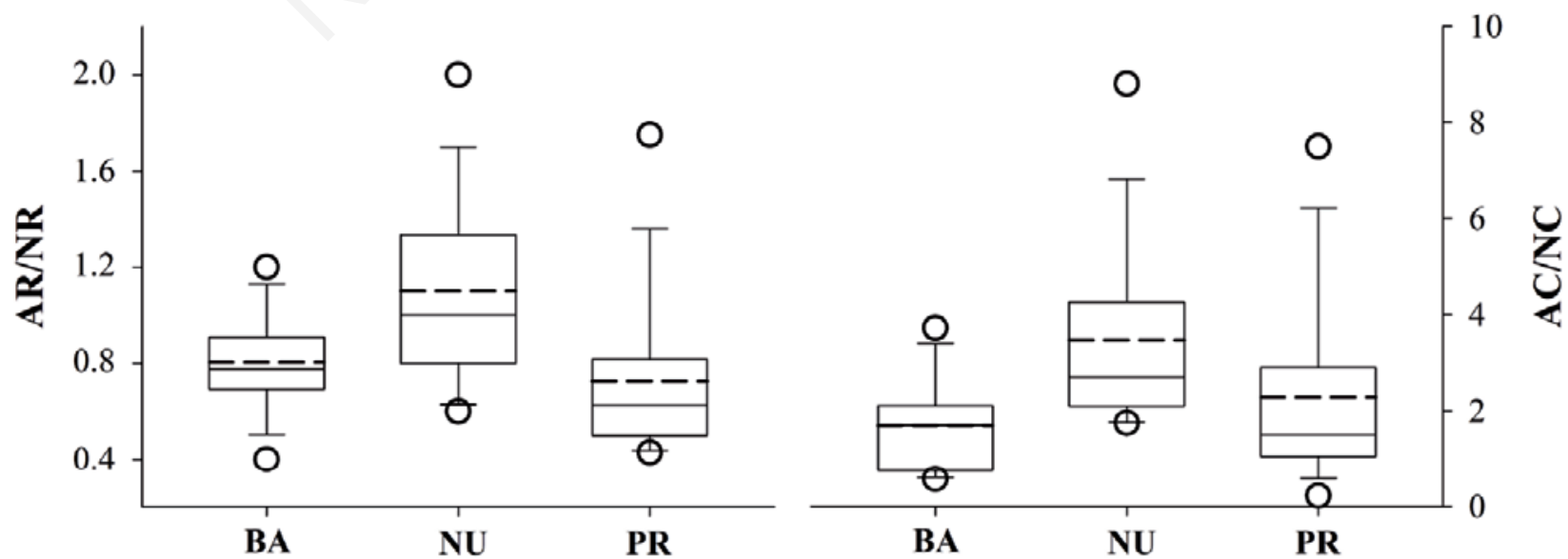

Fig. 4. Box-whiskers plots (minimum, 25\%, median, mean $=$ short-dashed line, $75 \%$, maximum, and outliers $=$ dots) showing variability $(\mathrm{n}=15)$ between rivers (BA, Baganza; NU, Nure; PR, Parma) in the ratio between alien and native species richness (AR/NR; left panel) and between alien and native species cover (AC/NC; right panel). 
other studies that suggest that plants living within riparian corridors are primarily driven by climate and hydrogeomorphic disturbance, including sediment texture and cohesion (Nobis and Skórka, 2015; Gurnell et al., 2016). Additionally, the structure and complexity of riparian vegetation are strictly related to the level and flow of waters and, consequently, to the saturation of substrates (Hood and Naiman 2000; Gurnell et al., 2016). These factors, in turn, depend on several other factors, including the size of the watercourse, the characteristics of its longitudinal and transverse profile morphology, the prevalent uses of soil and lithology at the basin scale, as well as the groundwater-surface water interactions (Leyer, 2006; Kuglerova et al., 2015; Nobis and Skórka, 2015; Gurnell et al., 2016).

The present data completes these prior results widening their applicability to the plant communities typical of the riverine emerged sediments, with special reference to the contribution of hydrological disturbance in structuring the in-stream dry ephemeral vegetation. The present study suggests a progressive decrease in species richness with the increase in hydrological disturbance expressed in terms of HT level (= altitudinal arrangement of plots above water base flow) as proxy of the three-dimensional complexity of the investigated stream stretch (Tabacchi et al., 1996). On the other hand, a more prolonged exposure of riverbeds may allow a greater development of pioneer plant coenoses directly associated with the establishment of a higher number of alien plants.

Indeed, a key contribution of alien species in terms of diversity has also been quantified in the studied streams, strengthening the idea of the centrality of river corridors as preeminent spreading paths for biological invasion in freshwaters and associated habitats (Lazzaro et al., 2020; Bolpagni, 2021). In the present case, the increase in plant cover-abundance rates that occurs concurrently with the in- crease in hydrological disconnection is partly attributable to the increase in the cover rates of alien species, which are largely to be considered as ruderal species not strictly riparian (following the classification by Tabacchi et al., 1996). Among these species, in fact, several taxa are included that are often common in agricultural and dry ruderal contexts, therefore not subject to regular flooding events [e.g., Ambrosia artemisiifolia, Digitaria sanguinalis (L.) Scop., Euphorbia nutans Lag., Setaria italica ssp. viridis]. This suggests a progressive replacement of the plants typical of exposed riverbeds by ruderal species, only marginally adapted to the more dynamic riverbed sectors. However, this is one of the first steps towards linking the structure of pioneer riverine vegetation with its ecological determinants (e.g., hydrology first and foremost) and no definitive evidence has yet been found. It seems, however, that the ruderal species richness mirrors the disturbance level within the river corridor, and in turn the degree of proximity of cultivated areas to the riverine habitats. The progressive lack of riverine ecotones boosts the spread of invaders into riverbeds from adjacent cultivated areas (Tabacchi et al., 1996). Nevertheless, additional studies are needed to explore the dynamics of this kind of plants and habitats, as well as to quantify the "biotic acceptance" trajectories of in-stream plant communities.

This represents an urgent issue due to the drastic reduction in summer base-flow rates observed in several temperate regions, including the Po plain in the last decades (Datry et al., 2014; Laini et al., 2020; Messager et al., 2021). In the presence of prolonged summer drought events, an increasing homogenization in terms of species could be expected to the advantage of ruderal plants. Indeed, the present data suggests an increase of local relevance of alien species along gradients of drought stress. However, there is only limited data indicative of the biological or functional

Tab. 2. Statistical output of the linear mixed models. p-values $<0.05$ are highlighted in bold, as the corresponding estimate and explanatory variable (ExpVar). The sign of the estimate value indicates the sign of the relationship between explanatory (HT, height above water base flow level; ST, surface sediment texture) and response variable (Res_var; TR, total richness; NR, native species richness; AR, alien species richness; AR/NR, ratio between alien and native species richness; AC/NC, ratio between alien and native species cover). In the model formula, (1|Site) indicates the random effect.

\begin{tabular}{|c|c|c|c|c|c|c|c|}
\hline Res_var & Model & ExpVar & Estimate & SE & Df & t value & p-value \\
\hline $\mathrm{TR}$ & $\mathrm{TR} \sim \mathrm{ST}+\mathrm{HT}+(1 \mid \mathrm{Site})$ & $\begin{array}{l}\text { ST } \\
\text { HT }\end{array}$ & $\begin{array}{c}-4.018 \\
\mathbf{0 . 0 9 1}\end{array}$ & $\begin{array}{l}3.138 \\
0.030\end{array}$ & $\begin{array}{l}37.768 \\
38.000\end{array}$ & $\begin{array}{c}-1.280 \\
3.069\end{array}$ & $\begin{array}{l}0.208 \\
\mathbf{0 . 0 0 4}\end{array}$ \\
\hline NR & $\mathrm{NR} \sim \mathrm{ST}+\mathrm{HT}+(1 \mid$ Site $)$ & $\begin{array}{l}\text { ST } \\
\text { HT }\end{array}$ & $\begin{array}{c}-1.802 \\
\mathbf{0 . 0 6 5}\end{array}$ & $\begin{array}{l}2.011 \\
0.019\end{array}$ & $\begin{array}{l}37.598 \\
37.944\end{array}$ & $\begin{array}{c}-0.896 \\
3.400\end{array}$ & $\begin{array}{l}0.376 \\
\mathbf{0 . 0 0 2}\end{array}$ \\
\hline $\mathrm{AR}$ & $\mathrm{AR} \sim \mathrm{ST}+\mathrm{HT}+(1 \mid$ Site $)$ & $\begin{array}{l}\text { ST } \\
\text { HT }\end{array}$ & $\begin{array}{c}-2.193 \\
0.028\end{array}$ & $\begin{array}{l}1.461 \\
0.014\end{array}$ & $\begin{array}{l}37.681 \\
37.987\end{array}$ & $\begin{array}{c}-1.501 \\
1.997\end{array}$ & $\begin{array}{l}0.142 \\
0.053\end{array}$ \\
\hline $\mathrm{AR} / \mathrm{NR}$ & $\mathrm{AR} / \mathrm{NR} \sim \mathrm{HT}+\mathrm{ST}+(1 \mid$ Site $)$ & $\begin{array}{l}\text { HT } \\
\text { ST }\end{array}$ & $\begin{array}{l}-0.002 \\
-0.098\end{array}$ & $\begin{array}{l}0.001 \\
0.151\end{array}$ & $\begin{array}{l}37.715 \\
37.320\end{array}$ & $\begin{array}{l}-1.681 \\
-0.651\end{array}$ & $\begin{array}{l}0.101 \\
0.519\end{array}$ \\
\hline $\mathrm{AC} / \mathrm{NC}$ & $\mathrm{AC} / \mathrm{NC} \sim \mathrm{HT}+\mathrm{ST}+(1 \mid$ Site $)$ & $\begin{array}{l}\text { HT } \\
\text { ST }\end{array}$ & $\begin{array}{c}\mathbf{0 . 0 1 7} \\
-0.654\end{array}$ & $\begin{array}{l}0.007 \\
0.775\end{array}$ & $\begin{array}{l}34.908 \\
37.465\end{array}$ & $\begin{array}{c}2.378 \\
-0.843\end{array}$ & $\begin{array}{l}\mathbf{0 . 0 2 3} \\
0.405\end{array}$ \\
\hline
\end{tabular}

$\overline{S E}$, standard error; $D f$, degrees of freedom. 
consequences mediated by the above-mentioned processes. This increases the uncertainty of global predictive models on the contribution of river networks (especially those of lowlands) to the cycles of $\mathrm{C}$ and nutrients at large scales (Mallast et al., 2020).

Furthermore, despite the ephemeral in-stream plant communities belonging to habitats defined of community interest in the Habitat Directive 92/43/CEE, a systematic, ecological perspective for their management is largely lacking, as well as a global synthesis of the numerous local studies who investigated them, as for example Lastrucci et al. (2010), Angiolini et al. (2017), and Guareschi et al. (2020) for Italy. Few research, in fact, has explored their ecological determinants to integrate the analysis of their composition and structure at large biogeographical scales (Brandes, 1999; Leuschner and Ellenberg, 2017), thus reducing the possibility to draw up adequate conservation plans. For example, regarding a widely discussed principle of freshwater restoration, the ecological flow, the repercussions of hydrological regulation on dry river domains have only recently begun to be evaluated along with the increased awareness on the unique value of dry beds globally (Steward et al., 2012). In this respect, the analysis of the annual "terrestrial" plants needs to be fully integrated into river monitoring programs, especially in non-perennial streams and rivers.

\section{CONCLUSIONS}

The pioneer vegetation of periodically exposed sediments plays pivotal ecological roles, representing an essential component of river ecosystems. Here, new insights on the role of hydrology and sediment quality in driving annual plant biodiversity have been offered to implement the knowledge of this neglected biological component of river ecosystems. Hydrological regulation and potential imbalances in the use of water at the basin scale may seriously affect the dynamics of this kind of plant communities, calling for the adoption of management practices that consider the ecological requirements and trajectories of the plant communities established in river corridors, not exclusively the arboreal ones. Furthermore, the present data stresses the importance of detailed monitoring studies - as well as modelling tools - on the local effects of climate change and direct human impacts to in-stream plants and vegetation dynamics. This is essential to further new or integrated eco- and hydro-geomorphological flow concepts in both regulated and unregulated rivers/basins.

\section{ACKNOWLEDGEMENTS}

A special thank goes to L. Paduano for the help in in the organization and carrying out of field and laboratory works. We also acknowledge the two anonymous reviewers for their valuable time, dedication, and important contributions that helped us to improve significatively the quality of the paper. Alice Dalla Vecchia has benefited from the equipment and framework of the COMP-HUB Initiative (Department of Chemistry, Life Sciences and Environmental Sustainability of Parma University), funded by the "Departments of Excellence" program of the Italian Ministry for Education, University and Research (MIUR, 2018-2022).

\section{REFERENCES}

Angiolini C, Viciani D, Bonari G, Lastrucci L, 2017. Habitat conservation prioritization: A floristic approach applied to a Mediterranean wetland network. Plant Biosyst. 151:598-612

Banfi E, Galasso G, 2010. [La flora esotica lombarda].[Book in Italian]. Museo di Storia Naturale di Milano, Milano: 273 pp.

Bartolucci F, Peruzzi L, Galasso G, Albano A, Alessandrini A, Ardenghi NMG, Astuti G, Bacchetta G, Ballelli S, Banfi E, Barberis G, Bernardo L, Bouvet D, Bovio M, Cecchi L, Di Pietro R, Domina G, Fascetti S, Fenu G, Festi F, Foggi B, Gallo L, Gottschlich G, Gubellini L, Iamonico D, Iberite M, JiménezMejías P, Lattanzi E, Marchetti D, Martinetto E, Masin RR, Medagli P, Passalacqua NG, Peccenini S, Pennesi R, Pierini B, Poldini L, Prosser F, Raimondo FM, Roma-Marzio F, Rosati L, Santangelo A, Scoppola A, Scortegagna S, Selvaggi A, Selvi F, Soldano A, Stinca A, Wagensommer RP, Wilhalm T, Conti F, 2018. An updated checklist of the vascular flora native to Italy. Plant Biosyst. 152:179-303.

Bolpagni R, 2021. Towards global dominance of invasive alien plants in freshwater ecosystems: the dawn of the Exocene? Hydrobiologia 848:2259-2279.

Bolpagni R, Piotti A, 2015. Hydro-hygrophilous vegetation diversity and distribution patterns in riverine wetlands in an agricultural landscape: A case study from the Oglio River (Po Plain, Northern Italy). Phytocoenologia 45: 69-84.

Bolpagni R, Piotti A, 2016. The importance of being natural in a human-altered riverscape: Role of wetland type in supporting habitat heterogeneity and the functional diversity of vegetation. Aquat. Conserv. 26:1168-1183.

Bolpagni R, Folegot S, Laini A, Bartoli M, 2017. Role of ephemeral vegetation of emerging river bottoms in modulating $\mathrm{CO}_{2}$ exchanges across a temperate large lowland river stretch. Aquat. Sci. 79:149-158.

Bolpagni R, Laini A, Mutti T, Viaroli P, Bartoli M, 2019. Connectivity and habitat typology drive $\mathrm{CO}_{2}$ and $\mathrm{CH}_{4}$ fluxes across land-water interfaces in lowland rivers. Ecohydrology 12:e2036.

Brandes D, 1999. Bidentetea-Arten an der mittleren Elbe. Braunschw.naturkdl.Schr. 5:781-809.

Burgazzi G, Laini A, Racchetti E, Viaroli P, 2017. Mesohabitat mosaic in lowland braided rivers: Short-term variability of macroinvertebrate metacommunities. J. Limnol. 76:1650.

Burgazzi G, Bolpagni R, Laini A, Racchetti E, Viaroli P, 2020. Algal biomass and macroinvertebrate dynamics in intermittent braided rivers: new perspectives from instream pools. River Res. Appl. 36: 1682-1689. 
Burkart M, 2001. River corridor plants (Stromtalpflanzen) in Central European lowland: A review of a poorly understood plant distribution pattern. Glob. Ecol. Biogeogr. 10:449-468.

Chytrý M, Otýpková Z, 2003. Plot sizes used for phytosociological sampling of European vegetation. J. Veg. Sci. 14:563-570.

Corenblit D, Tabacchi E, Steiger J, Gurnell AM, 2007. Reciprocal interactions and adjustments between fluvial landforms and vegetation dynamics in river corridors: a review of complementary approaches. Earth Sci. Rev. 84:56-86.

Corenblit D, Steiger J, González E, Gurnell AM, Charrier G, Darrozes J, Dousseau J, Julien F, Lambs L, Larrue S, Roussel E, Vautier F, Voldoire O, 2014. The biogeomorphological life cycle of poplars during the fluvial biogeomorphological succession: a special focus on Populus nigra L. Earth Surf. Process. Landf. 39:546-563.

Datry T, Larned ST, Tockner K, 2014. Intermittent rivers: a challenge for freshwater ecology. BioScience 64:229-235.

Galasso G, Conti F, Peruzzi L, Ardenghi NMG, Banfi E, Celesti-Grapow L, Albano A, Alessandrini A, Bacchetta G, Ballelli S, Bandini Mazzanti M, Barberis G, Bernardo L, Blasi C, Bouvet D, Bovio M, Cecchi L, Del Guacchio E, Domina G, Fascetti S, Gallo L, Gubellini L, Guiggi A, Iamonico D, Iberite M, Jiménez-Mejías P, Lattanzi E, Marchetti D, Martinetto E, Masin RR, Medagli P, Passalacqua NG, Peccenini S, Pennesi R, Pierini B, Podda L, Poldini L, Prosser F, Raimondo FM, Roma-Marzio F, Rosati L, Santangelo A, Scoppola A, Scortegagna S, Selvaggi A, Selvi F, Soldano A, Stinca A, Wagensommer RP, Wilhalm T, Bartolucci F, 2018. An updated checklist of the vascular flora alien to Italy. Plant Biosyst. 152:556-592.

Gómez-Gener L, Siebers AR, Arce MI, Arnon S, Bernal S, Bolpagni R, Datry T, Gionchetta G, Grossart H-P, MendozaLera C, Pohl V, Risse-Buhl U, Shumilova O, Tzoraki O, von Schiller D, Weigand A, Weigelhofer G, Zak D, Zoppini A, 2021. Towards an improved understanding of biogeochemical processes across surface-groundwater interactions in intermittent rivers and ephemeral streams, Earth-Sci. Rev. 220:103724.

Guareschi S, Laini A, Viaroli P, Bolpagni R, 2020. Integrating habitat- and species-based perspectives for wetland conservation in lowland agricultural landscapes. Biodivers. Conserv. 29:153-171.

Gurnell AM, Bertoldi W, Corenblit D, 2012. Changing river channels: the roles of hydrological processes, plants and pioneer landforms in humid temperate, mixed load, gravel bed rivers. Earth Sci. Rev. 111:129-141.

Gurnell AM, Corenblit D, De Jalón DG, Del Tánago MG, Grabowski RC, O'hare MT, Szewczyk M, 2016. A conceptual model of vegetation-hydrogeomorphology interactions within river corridors. River Res. Appl. 32:142-163.

Hood WG, Naiman RJ, 2000. Vulnerability of riparian zones to invasion by exotic vascular plants. Plant Ecol. 148:105-114.

Kuglerova L, Jansson R, Sponseller RA, Laudon H, MalmRenöfält B, 2015. Local and regional processes determine plant species richness in a river-network metacommunity. Ecology 96:381-391.

Kuznetsova A, Brockhoff P, Christensen RHB, 2017. lmerTest Package: Tests in Linear Mixed Effects Models. J. Stat. Softw. 82:1-26.
Laini A, Beermann AJ, Bolpagni R, Burgazzi G, Elbrecht V, Zizka VMA, Leese F, Viaroli P, 2020. Exploring the potential of metabarcoding to disentangle macroinvertebrate community dynamics in intermittent streams. MBMG 4:65-79.

Lastrucci L, Landi M, Angiolini C, 2010. Vegetation analysis on wetlands in a Tuscan agricultural landscape (central Italy). Biologia 65:54-68.

Lazzaro L, Bolpagni R, Buffa G, Gentili R, Lonati M, Stinca A, Acosta ATR, Adorni M, Aleffi M, Allegrezza M, Angiolini C, Assini S, Bagella S, Bonari G, Bovio M, Bracco F, Brundu G, Caccianiga M, Carnevali L, Di Cecco V, Ceschin S, Ciaschetti G, Cogoni A, Foggi B, Frattaroli AR, Genovesi P, Gigante D, Lucchese F, Mainetti A, Mariotti M, Minissale P, Paura B, Pellizzari M, Perrino EV, Pirone G, Poggio L, Poldini L, Poponessi S, Prisco I, Prosser F, Puglisi M, Rosati L, Selvaggi A, Sottovia L, Spampinato G, Stanisci A, Venanzoni R, Viciani D, Vidali M, Villani M, Lastrucci L, 2020. Impact of invasive alien plants on native plant communities and Natura 2000 habitats: State of the art, gap analysis and perspectives in Italy. J. Environ. Manage. 274:111140.

Leuschner C, Ellenberg H, 2017. Banks, Shorelines and Muddy Habitats Influenced by Man, p. 751-764. In: C. Leuschner and H. Ellenberg (eds.), Ecology of Central European NonForest Vegetation: Coastal to Alpine, Natural to Man-Made Habitats. Springer International Publishing.

Leyer I, 2006. Dispersal, diversity and distribution patterns in pioneer vegetation: The role of river-floodplain connectivity. J. Veg. Sci. 17:407-416.

Mallast U, Staniek M, Koschorreck M, 2020. Spatial upscaling of $\mathrm{CO}_{2}$ emissions from exposed river sediments of the Elbe River during an extreme drought. Ecohydrology 13(6):e2216.

Messager ML, Lehner B, Cockburn C, Lamouroux N, Pella H, Snelder T, Tockner K, Trautmann T, Watt V, Datry T, 2021. Global prevalence of non-perennial rivers and streams. Nature 594:391-397.

Nobis A, Skórka P, 2015. River corridor plants revisited: What drivers their unique distribution patterns? Plant Biosyst. 150:244-253.

Salisbury E, 1970. The Pioneer Vegetation of Exposed Muds and Its Biological Features. Philos. Trans. R. Soc. Lond. B Biol. Sci. 259:207-255.

Steward AL, von Schiller D, Tockner K, Marshall JC, Bunn SE, 2012. When the river runs dry: human and ecological values of dry riverbeds. Front. Ecol. Environ. 10:202-209.

R Core Team, 2021. R: A language and environment for statistical computing. Vienna, Austria: R Foundation for Statistical Computing. Retrieved from https://www.R-project.org/

Tabacchi E, Planty-Tabacchi A-M, Salinas MJ, Décamps H, 1996. Landscape structure and diversity in riparian plant communities: a longitudinal comparative study. Reg. Riv.: Res. Manage. 12:367-390.

Thomaz SM, da Cunha ER, 2010. The role of macrophytes in habitat structuring in aquatic ecosystems: methods of measurement, causes and consequences on animal assemblages' composition and biodiversity. Acta Limnol. Bras. 22:218-236.

Wolman MG, 1954. A Method of Sampling Coarse River-Bed Material. Trans. AGU 35:951-956 